\title{
Isolation and molecular characterization of New Delhi metallo-beta- lactamase-1 producing superbug in Bangladesh
}

\author{
Refath Farzana, S. M. Shamsuzzaman, Kazi Z. Mamun \\ Dhaka Medical College, Department of Microbiology, Dhaka, Bangladesh
}

\begin{abstract}
Introduction: New Delhi metallo-beta-lactamse-1 (NDM-1) producing superbugs create a global public health problem because of their resistance to most antibiotics. This study was conducted to determine the presence of MBL producers, including NDM-1 producers, in Bangladesh, along with the antimicrobial resistance patterns of these organisms.

Methodology: Thirty-five isolates resistant to imipenem by disk diffusion technique were investigated for MBL production. Minimum inhibitory concentration (MIC) of imipenem was determined by agar dilution method. MBL producers were phenotypically detected by double disk synergy test and combined disk assay. Gene encoding blaIMP-1, blaIMP-2, blaVIM-1, blaVIM-2, blaNDM-1 and class 1 integron was identified by PCR.

Results: Thirty-one (88.57\%) MBL producers were detected by PCR, 24 (68.57\%) by double disk synergy test, and 30 (85.71\%) by combined disk assay. Eight (22.86\%) were positive for blaNDM-1, 13 (37.15\%) for blaVIM-1, 21 (60.00\%) for blaVIM-2, 18 (51.43\%) for blaIMP-1, and $9(25.71 \%)$ for blaIMP-2. More than one blaMBL was present in $23(65.71 \%)$ of the isolates. MIC of imipenem of MBL producers ranged from $\geq 256 \mu \mathrm{g} / \mathrm{ml}$ to $\leq 8 \mu \mathrm{g} / \mathrm{ml}$. All the NDM-1 producing isolates carried class 1 integron. NDM- 1 producers were $100 \%$ resistant to amoxicillin, cephradine, cefuroxime, ceftazidime, cefotaxime, ceftriaxone, aztreonam, gentamicin and piperacillin, $87.5 \%$ to amikacin, $75 \%$ to ciprofloxacin, and $62.5 \%$ to co-trimoxazole and the combination of tazobactam and piperacillin. All were sensitive to colistin.

Conclusion: The results of this study provide insight into the presence of blaMBL, including blaNDM-1, in Bangladesh. Urgent epidemiological monitoring of MBL producers in Bangladesh may combat their rapid dissemination.
\end{abstract}

Key words: metallo-beta-lactamase; New Delhi metallo-beta-lactamase-1; Bangladesh; molecular characterization; antimicrobial susceptibility patterns

J Infect Dev Ctries 2013; 7(3):161-168.

(Received 02 January 2012 - Accepted 15 April 2012)

Copyright (C) 2013Farzana et al. This is an open-access article distributed under the Creative Commons Attribution License, which permits unrestricted use, distribution, and reproduction in any medium, provided the original work is properly cited.

\section{Introduction}

The global dissemination of acquired metallo-betalactamases (MBLs) in Gram-negative bacteria is a major cause of microbial resistance to beta-lactam antibiotics. MBLs are alarming because of their ability to hydrolyze all beta-lactams except aztreonam [1]. Most of the transposable MBLs encoding genes are carried on integrons as cassettes which facilitate their rapid spread among organisms and confer resistance to both beta-lactam and other antimicrobial agents. MBL encoding genes have been detected from several Gram-negative bacilli belonging to the family Enterobacteriaceaeand also in Pseudomonas species and Acinetobacter species [2]. Until now, multiple allelic variants of several MBLs have been described (http://www.lahey.org/studies/); VIMs and IMPs are the most frequent MBLs worldwide [3] and outbreaks of VIM and IMP type MBLs in the species of
Pseudomonas aeruginosawere reported from Greece, Italy, Korea and China [4-7]. Recently, a novel metallo-enzyme, New Delhi metallo-beta-lactamase-1 (NDM-1), was discovered in $K$. pneumoniae in a Swedish patient after treatment in a hospital in New Delhi, India [8] and it rapidly disseminated globally [9-12]. NDM-1 share only $32.4 \%$ amino acid sequence homology with the closely related VIM-1 / VIM-2 MBL producers and, with the exception of other MBL, transpose hastily to other bacteria by ISCRI element via rolling circle replication [8]. Rapid worldwide expansion of NDM-1 producers now creates a public health problem because they remain extensively resistant to nearly all antibiotics except colistin and tigecycline [9-11].

Considering the public health threat the MBL producers pose and the rapid dissemination of blaNDM-1 in bacteria, the search for the presence of 
MBL producers, including NDM-1 producers, in Bangladesh seems worthy. We undertook this study to explore the incidence of multidrug resistant MBL producers, including NDM-1 producers, in Bangladesh along with antimicrobial resistant patterns of these organisms.

\section{Methodology}

Bacterial isolates

We conducted a cross-sectional study in the Department of Microbiology of Dhaka Medical College, Dhaka, Bangladesh, during 1 July 2010 to 30 June 2011. This research protocol was approved by the research review committee (RRC) and ethical review committee (ERC) of Dhaka Medical College. Thirtyfive isolates resistant to imipenem by disk diffusion technique (according to Clinical and Laboratory Standards Institute [CLSI] guidelines) were investigated for MBL production in this study [13].

\section{Identification of species among the imipenem resistant isolates}

Samples collected from different sources were inoculated on MacConkey agar media and blood agar media. From the non-lactose fermenting colonies on MacConkey agar media, isolates were identified as Pseudomonas aureuginosa if they were oxidase positive, a triple sugar iron (TSI) agar reaction of alkaline over no change, motile, indole and urease negative in motility-indole-urea (MIU) agar media, citrate negative in simmons citrate agar media and grew at both $37^{\circ} \mathrm{C}$ and $42^{\circ} \mathrm{C}$. Additional bacterial characteristics including its Gram stain, colony morphology, hemolytic criteria, and pigment production were also used to identify the species. Nonlactose fermenting colonies on MacConkey agar were identified as Acinetobacter baumani if they were Gram-negative coccobacilli, oxidase negative, nonmotile, indole and urease negative, citrate positive and grew at $41^{\circ}$ Cand $44^{\circ}$ C.E. coli and $K$. pneumoniae were isolated and identified on Gram stain, colony morphology, hemolytic criteria, pigment production and biochemical tests as previously described [14-15].

\section{Antimicrobial susceptibility testing}

Following CLSI guidelines, antimicrobial susceptibility pattern of MBL producers was performed by disk diffusion technique using commercially available antibiotic disks (Oxoid Ltd, Basingstoke, United Kingdom). Escherichia coli ATCC 25922 was used for quality control [13].
Minimum inhibitory concentration of imipenem

The minimum inhibitory concentration (MIC) of imipenem of 35 isolates was determined by agar dilution method [16]. To prepare imipenem stock solution, $500 \mathrm{mg}$ imipenem powder was added to 50 $\mathrm{ml}$ distilled water. Next, $50 \mathrm{ml}$ sterile Mueller-Hinton agar was impregnated with $40 \mu 1,80 \mu 1,160 \mu 1,320$ $\mu 1,640 \mu \mathrm{l}$ and $1280 \mu \mathrm{l}$ of imipenem stock solution to achieve concentrations of $8 \mu \mathrm{g} / \mathrm{ml}, 16 \mu \mathrm{g} / \mathrm{ml}, 32$ $\mu \mathrm{g} / \mathrm{ml}, 64 \mu \mathrm{g} / \mathrm{ml}, 128 \mu \mathrm{g} / \mathrm{ml}$ and $256 \mu \mathrm{g} / \mathrm{ml}$ per plate, respectively. To obtain $10^{4} \mathrm{cfu} / \mathrm{spot}$ on the agar surface, one $\mu \mathrm{l}$ of 10 times diluted $0.5 \mathrm{McF}$ arland turbidity of test inoculums were placed on Mueller-Hinton agar plates. After incubation at $35^{\circ} \mathrm{C}$ overnight, the lowest concentration of antibiotic impregnated MuellerHinton agar showing no visible growth on agar medium was considered the MIC of imipenem of that strain.

\section{Detection of $M B L$ producers by phenotypic methods}

Double-disk synergy tests (DDS) [17] and combined disk (CD) assays [18] were performed to screen MBLs producers. For the DDS test, imipenem and a blank disk containing $20 \mu \mathrm{l}$ of Tris-EDTA (1.0 M Tris - HCL, 0.1 M EDTA, $\mathrm{pH}$ approximately 8.0) and $20 \mu 1$ of 1:320 diluted 2-mercaptopropionic acid (MPA) were placed $10 \mathrm{~mm}$ apart in an inoculated Mueller-Hinton agar plate and incubated at $37^{\circ} \mathrm{C}$ for 24 hours. A clear extension of the edge of the inhibition zone of imipenem disk toward the TrisEDTA-MPA disk was interpreted as MBLs production. For the $\mathrm{CD}$ assay, two imipenem disks were placed on an inoculated Mueller-Hinton agar plate. One imipenem disk was supplemented with $5 \mu 1$ of $0.5 \mathrm{M}$ EDTA and incubated at $37^{\circ} \mathrm{C}$ for 24 hours. An increased zone diameter of $\geq 6 \mathrm{~mm}$ around the disk containing imipenem supplemented with EDTA compared to the disk containing imipenem alone was interpreted as MBLs production.

\section{Molecular characterization of MBL producers}

The presence of blaNDM-1, blaIMP-1, blaIMP-2, blaVIM-1 and blaVIM-2 among the imipenemresistant isolates was detected by polymerase chain reaction (PCR). Class 1 integron was also identified among the imipenem-resistant strains by PCR. To prepare bacterial pellets, a loop full of bacterial colonies was inoculated into a Falcon tube containing trypticase soy broth. After incubation overnight at $37^{\circ} \mathrm{C}$, the Falcon tubes were centrifuged at $4,000 \mathrm{rpm}$ for 10 minutes, after which the supernatant was discarded. A small amount of sterile trypticase soy 
broth was added into the Falcon tubes with pellets and mixed evenly. Then an equal amount of bacterial suspension was placed into 2 to 3 to Eppendorf tubes. The Eppendorf tubes were then centrifuged at 4,000 rpm for 10 minutes and the supernatant was discarded. The Eppendorf tubes containing bacterial pellets were kept at $-20^{\circ} \mathrm{C}$ until DNA extraction. Bacterial DNA was extracted by the boiling method [19]. The following pairs of previously used primers were used to yield PCR products: for blaNDM-1- ACC GCC TGG ACC GAT GAC CA (forward), GCC AAA GTT GGG CGC GGT TG (reverse), for blaIMP-1TGAGCAAGTTATCTGTATTC (forward), TTAGTTGCTTGGTTTTGATG (reverse), for blaIMP-2- GGCAGTCGCCCTAAAACAAA (forward), TAGTTACTTGGCTGTGATGG (reverse), for blaVIM-1 - TTATGGAGCAGCAACCGATGT (forward), CAAAAGTCCCGCTCCAACGA (reverse), for blaVIM-2AAAGTTATGCCGCACTCACC (forward), TGCAACTTCATGTTATGCCG (reverse) and for class 1 integron- GGC ATC CAA GCA GCA AGC (forward), AAG CAG ACT TGA CCT GAT (reverse) [19-21]. The following cycling parameters were used: initial denaturation at $95^{\circ} \mathrm{C}$ for 10 minutes, then 30 cycles of denaturation at $95^{\circ} \mathrm{C}$ for one minute, annealing at $63^{\circ} \mathrm{C}$ (for blaNDM-1), $57^{\circ} \mathrm{C}$ (for bla IMP1), $60^{\circ} \mathrm{C}$ (for bla IMP-2), $60^{\circ} \mathrm{C}$ (for blaVIM-1), $59^{\circ} \mathrm{C}$ (for blaVIM-2) and $58^{\circ} \mathrm{C}$ (for class 1 integron) for 45 seconds, extension at $72^{\circ} \mathrm{C}$ for one minute and 30 seconds, and a final extension at $72^{\circ} \mathrm{C}$ for 10 minutes. The amplified DNA were loaded into a $1.5 \%$ agarosegel, electrophoresed at 100 volts for 35 minutes, stained with $1 \%$ ethidium bromide, and visualized under UV light.

\section{Statistical analysis}

Data were analyzed by using Microsoft Excel (2007) software (Microsoft, Redmond, WA, USA).

\section{Results}

A total of 35 imipenem-resistant strains by disk diffusion technique were included in this study. Fifteen Acinetobacterbaumanni, sixteen Pseudomonas aeruginosa, three E. coli and one $K$. pneumonia were isolated from the imipenem-resistant organisms. The MIC of imipenem of these isolates ranged from $\geq 256$ $\mu \mathrm{g} / \mathrm{ml}$ to $\leq 8 \mu \mathrm{g} / \mathrm{ml}$ (Figure).

Thirty-one $(88.57 \%)$ MBL producers were detected by PCR, of which $8(22.86 \%)$ were positive for blaNDM-1, 13 (37.15\%) for blaVIM-1,23 (65.71\%) for blaVIM-2, 18 (51.43\%) for blaIMP-1 and $9(25.71 \%)$ for blaIMP-2. All (100\%) imipenemresistant Acinetobacter baumanni, $14(87.50 \%)$ of the 16 Pseudomonas aeruginosa, one (33.33\%) of the $3 E$. coli and the only $K$. pneumoniae were positive for blaMBL by PCR. Twenty-three $(65.71 \%)$ isolates carried more than one MBL gene, 8 (22.86\%) carried a single MBL gene, and 4 (11.43\%) had no MBL gene.

The DDS tests and CD assays detected 24 $(68.57 \%)$ and $30 \quad(85.71 \%)$ MBL producers, respectively, among the 35 imipenem-resistant isolates. Out of the four negative amplified PCR products, three were positive by DDS test and all were

Figure. PCR detection of blaNDM-1 gene among 7 imipenem resistant strains

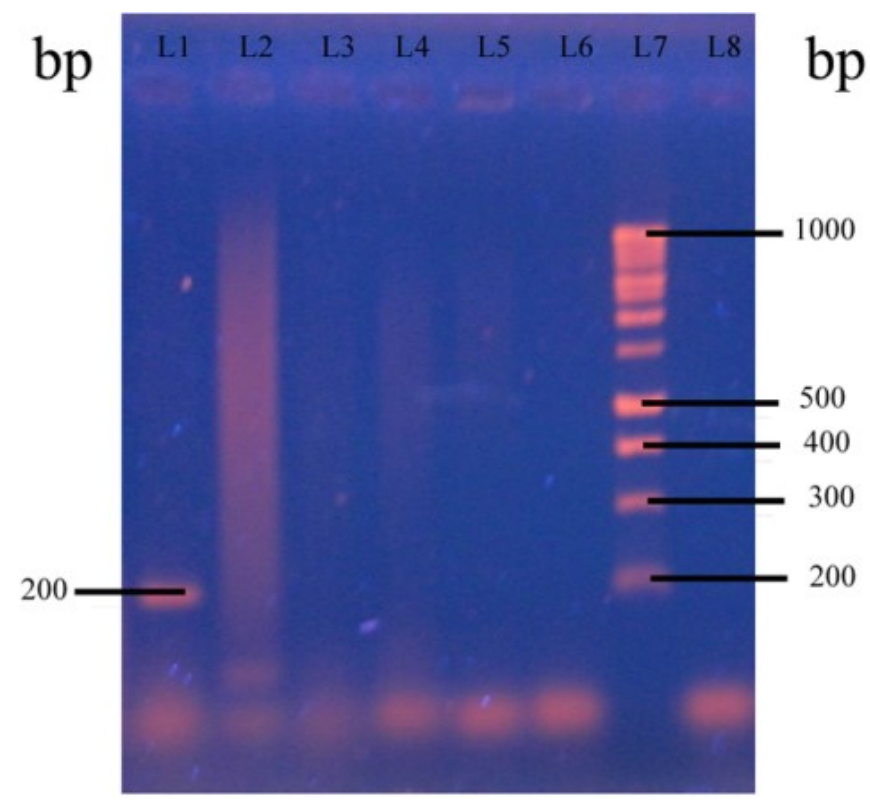


positive by CD assay. Sensitivity of the phenotypic methods considering PCR as gold standard was $67.74 \%$ for DDS test and $83.87 \%$ for CD assay.

Twenty-three (74\%) of the MBL-producing isolates were positive for class 1 integron and $3(75 \%)$ of the 4 non-MBL producers had class 1 integron. All the NDM-1 producing isolates had the class 1 integron (Table 1).

The combinations of different genes in single strains were observed. Table 1 shows that, among them, blaVIM-2 + blaIMP-1 + class 1 integron was the predominant variety, which was present in four $(11.43 \%)$ of the isolates. blaNDM-1 was present with other blaMBLs and class 1 integron in different combinations.
Table 2 illustrates MIC of imipenem among different species of MBL producers. Isolates that were negative for MBLs production by PCR had $\geq 256$ $\mu \mathrm{g} / \mathrm{ml}$ MIC of imipenem for three (75\%) isolates and $128 \mu \mathrm{g} / \mathrm{ml}$ for one $(25 \%)$ isolate.

All the MBL producers were $100 \%$ resistant to amoxicillin, cephradine, cefuroxime, ceftazidime, cefotaxime, ceftriaxone, gentamicin and piperacillin, $96.77 \%$ to amikacin, $93.55 \%$ to ciprofloxacin, $87.09 \%$ to co-trimoxazole, $80.64 \%$ to the combination of tazobactam and piperacillin, and $67.74 \%$ to aztreonam. All the MBL-producing isolates were sensitive to colistin.

Resistance to antimicrobials among the NDM-1 producing isolates was $100 \%$ for amoxicillin,

Table 1. Distribution of blaMBLs and class 1 integron among the imipenem resistant strains $(\mathrm{n}=35)$

\begin{tabular}{|c|c|c|}
\hline Genotypes & Number amplified & Organisms \\
\hline blaVIM-2 + blaIMP-1 & $2(5.71 \%)$ & $\begin{array}{l}\text { A. baumanni }(1) \\
\text { P. aeruginosa }(1)\end{array}$ \\
\hline blaVIM-1 + blaVIM-2 & $1(2.86 \%)$ & A. baumanni (1) \\
\hline blaVIM-2 + blaIMP-2 & $1(2.86 \%)$ & P. aeruginosa (1) \\
\hline blaVIM-1 + class 1 integron & $1(2.86 \%)$ & $P$. aeruginosa $(1)$ \\
\hline blaVIM-2 + class 1 integron & $2(5.71 \%)$ & $\begin{array}{l}\text { A. baumanni }(1) \\
\text { P. aeruginosa }(1)\end{array}$ \\
\hline blaNDM-1 + class 1 integron & $2(5.71 \%)$ & $\begin{array}{l}\text { P. aeruginosa }(1) \\
\text { A. baumanni }(1)\end{array}$ \\
\hline blaVIM-2 + blaIMP-1 + blaIMP-2 & $1(2.86 \%)$ & A. baumanni (1) \\
\hline blaVIM-2 + blaIMP-1 + class 1 integron & $4(11.43 \%)$ & $\begin{array}{l}\text { A. baumanni }(1) \\
\text { P. aeruginosa }(3)\end{array}$ \\
\hline blaVIM-1 + blaIMP-1 + class 1 integron & $2(5.71 \%)$ & A. baumanni (2) \\
\hline blaVIM-2 + blaNDM-1 + class 1 integron & $1(2.86 \%)$ & P. aeruginosa $(1)$ \\
\hline blaIMP-1 + blaIMP-2 + class 1 integron & $1(2.86 \%)$ & P. aeruginosa $(1)$ \\
\hline blaVIM-1 + blaVIM-2 + blaIMP-1 + class 1 integron & $3(8.57 \%)$ & $\begin{array}{l}\text { P. aeruginosa }(1) \\
\text { A. baumanni }(2)\end{array}$ \\
\hline blaVIM-2 + blaIMP-1 + blaIMP-2 + class 1 integron & $2(5.71 \%)$ & A. baumanni (2) \\
\hline blaVIM-1 + blaVIM-2 + blaNDM-1 + class 1 integron & $1(2.86 \%)$ & K. pneumonia (1) \\
\hline $\begin{array}{l}\text { blaVIM-1 + blaVIM-2 + blaIMP-2 + blaNDM-1 + class } \\
1 \text { integron }\end{array}$ & $2(5.71 \%)$ & $\begin{array}{l}\text { A. baumanni }(1) \\
\text { P. aeruginosa }(1)\end{array}$ \\
\hline $\begin{array}{l}\text { blaVIM-1 + blaVIM-2 + blaIMP-1 + blaIMP-2 + } \\
\text { blaNDM-1 + class } 1 \text { integron }\end{array}$ & $2(5.71 \%)$ & A. baumanni (2) \\
\hline blaVIM-1 & $1(2.86 \%)$ & P. aeruginosa $(1)$ \\
\hline blaVIM-2 & $1(2.86 \%)$ & P. aeruginosa $(1)$ \\
\hline blaIMP-1 & $1(2.86 \%)$ & E. $\operatorname{coli}(1)$ \\
\hline Class 1 integron & $3(8.57 \%)$ & $\begin{array}{l}\text { E. coli }(1) \\
\text { P. aeruginosa }(2)\end{array}$ \\
\hline Absence of examined genes & $1(2.86 \%)$ & E. $\operatorname{coli}(1)$ \\
\hline
\end{tabular}

* Figures in parentheses in the last column indicate number of isolates. 
Table 2. MIC of imipenem among MBL producers

\begin{tabular}{|c|c|c|c|c|c|c|}
\hline \multirow{2}{*}{ MBL producers } & \multicolumn{6}{|c|}{ MIC of imipenem $(\mu \mathrm{g} / \mathrm{ml})$} \\
\hline & $\geq 256$ & 128 & 64 & 32 & 16 & $\leq 8$ \\
\hline A. baumanni $(\mathrm{n}=15)$ & $6(40.00)$ & $0(0.00)$ & $2(13.33)$ & $5(33.33)$ & $1(6.67)$ & $1(6.67)$ \\
\hline P. aeruginosa $(\mathrm{n}=14)$ & $4(28.58)$ & $3(21.42)$ & $4(28.58)$ & $1(7.14)$ & $1(7.14)$ & $1(7.14)$ \\
\hline E. $\operatorname{coli}(\mathrm{n}=1)$ & - & $1(100.00)$ & - & - & - & - \\
\hline K. pneumoniae $(\mathrm{n}=1)$ & $1(100.00)$ & - & - & - & - & - \\
\hline Total $(n=31)$ & $11(35.48)$ & $4(12.90)$ & $6(19.35)$ & $6(19.35)$ & $2(6.46)$ & $2(6.46)$ \\
\hline
\end{tabular}

* Figures in parentheses represent percentage.

cephradine, cefuroxime, ceftazidime, cefotaxime, ceftriaxone, aztreonam, gentamicin and piperacillin, $87.5 \%$ for amikacin, $75 \%$ for ciprofloxacin, and $62.5 \%$ for co-trimoxazole and the combination of tazobactam and piperacillin.

\section{Discussion}

Acquired MBLs in Gram-negative bacteria are becoming an emerging resistant determinant worldwide [1]. The continuous monitoring and rapid detection of these virulent organisms may check their spread and play a vital role in infection control. To address this rising resistant determinant, we have observed the distribution of MBL encoding genes among the imipenem-resistant isolates in Bangladesh. The present study identified 31 (88.57\%) MBL producers out of the 35 imipenem-resistant bacteria. All the imipenem resistant Acinetobacterbaumanni, $87.50 \%$ of the Pseudomonas aeruginosa, $33.33 \%$ of the E. coli and the only $K$. pneumoniae had MBL genes. Though acquired MBL encoding genes are frequently found in Pseudomonas spp. and Acinetobacter spp., the existence of MBL encoding genes in the species of E. coli and $K$. pneumoniae in this study suggests that plasmid-mediated horizontal transfer of the MBL genes occurs continuously among Gram-negative bacilli, as reported previously [2].

Interestingly, most of the cases from Europe, America, and Australia had a history of recent travel or hospital admission in the Indian subcontinent. NDM-1 producers are now alarmingly rising worldwide and pose potential therapeutic failures with current empirical treatments in place [9-11]. The results of the current study reflect the presence of NDM-1 producers in Bangladesh. Inappropriate and non-prescription antibiotic use might be the probable cause of development of high antimicrobial resistance in this subcontinent [22]. In addition, with NDM-1 producers, the current study found 13 (37.15\%) VIM$1,23(65.71 \%)$ VIM-2, 18 (51.43\%) IMP-1 and 9 (25.71\%) IMP-2 producers among the imipenemresistant bacteria. The presence of VIM-1, VIM-2, IMP-1 and IMP-2 in Pseudomonas spp., Acinetobacter spp., and the members of Enterobacteriaceae has been described previously [23-28]. The findings of the present study indicate the dissemination of blaMBLcarrying organisms in Bangladesh.

The present study observed $23(74 \%)$ class 1 integron-carrying MBL producers. Most of the acquired blaMBLs were the part of integron and resided in large transmissible plasmids [29]. In agreement with the present findings, earlier studies observed the presence of the class 1 integron with blaMBLs [30-31]; the clonal relatedness of three VIM-1 producing Pseudomonas spp. isolated from three different hospitals, along with the observed presence of specific genotyped integrons within them suggest that they share a common ancestry [31]. Therefore, the presence of conserved integron associated with blaMBLs in epidemiologically unrelated strains indicates the possibility of worldwide dissemination. Though genome sequencing was not performed in this study, the existence of class 1 integron in MBL producers suggests the probable association among them. In this study, all the NDM-1 producers had class 1 integron. The results of a previous study that observed the presence of blaNDM1 and ISCR 1 suggest that blaNDM-1 and ISCR1 have the same genetic structure and that the strain also has class 1 integron [9]. However, the association between blaNDM-1 and the class 1 integron or ISCR 1 elements was not ascertained in this study.

A survey in rural Bangladesh demonstrated multiple transferable resistances in enteric flora [32], which may serve as reservoirs of antimicrobial resistance among the enteric pathogens. The present 
study observed the presence of more than one MBL gene in $23(65.71 \%)$ imipenem-resistant isolates. As acquired blaMBLs have the ability to transfer to other organisms via the integrons located in plasmids or transposons [29], reserved resistance determinants might relocate to other plasmids or other bacteria, explaining the existence of more than one antimicrobial resistance mechanism in a single strain.

The sensitivity of the DDS tests and CD assays for bacterial MBLs detection was $67.74 \%$ and $83.87 \%$, respectively, considering PCR as the gold standard. As the zinc chelators also diminish the action of OXA carbapenemase [33], phenotypic methods might provide positive inference among the negative amplifiers. However, screening of OXA carbapenemase was not performed in this investigation.

In this study, among the MBL producers, the MIC of imipenem ranged from $\geq 256 \mu \mathrm{g} / \mathrm{ml}$ to $8 \mu \mathrm{g} / \mathrm{ml}$ (Table 2), which was similar to the findings of earlier studies [34-35]. The discrepancy in the level of imipenem resistance for MBL producers might be due to variations in the permeation capacity of imipenem through bacterial outer membranes [36]. In our study, four $(11.53 \%)$ of the imipenem-resistant isolates showed negative amplification by PCR. The MIC of these strains was $\geq 256 \mu \mathrm{g} / \mathrm{ml}$ for three $(75 \%)$ isolates and $128 \mu \mathrm{g} / \mathrm{ml}$ for one $(25 \%)$ isolate. The high imipenem resistance among the non-MBL producers in this study might be due to resistance mechanisms other than MBL production [37]. However, the presence of blaMBLs other than the examined MBL genes among these strains also might be the reason behind it.

In this study, MBL producers were viewed as multidrug resistant. Selective pressure and/or the simultaneous presence of other drug resistance genes such as gene cassettes or other resistance mechanisms might be the reason for the co-resistance [2, 38-39]. High doses of aztreonam or tazobactam-piperacillin cure rats from experimental pneumonia by reducing MBL-producing strains [40]. But in this study, 67.74\% of the MBL producers were resistant to aztreonam and $80.64 \%$ to the combination of tazobactam-piperacillin. A previous study demonstrated the overexpression of efflux genes and AmpC coupled with down-regulation of oprD in respect to antimicrobial resistance, and found the association of blaMBLs with efflux genes and/or AmpC $\beta$-lactamase genes, describing this resistance among the MBL producers [39]. The use of the most sensitive antibiotic, colistin, is limited due to its neurotoxicity and nephrotoxicity [41]. However, very recently reversible colistin-induced nephrotoxicity was reported in carbapenem-resistant bacterial infection [42]. It is necessary to evaluate in vitro activities of two or more antimicrobial agents against MBL producers.

\section{Conclusion}

The high incidence of MBLs in our study among imipenem-resistant Gram-negative organisms highlights the emerging therapeutic challenge in Bangladesh. Early detection of this resistance mechanism, implementation of strict antimicrobial policies and infection control programs may avoid the rapid dissemination of these organisms.

\section{Acknowledgements}

Department of Microbiology, Dhaka Medical College, Dhaka provided financial and laboratory support to perform this study. We thank the Bangladesh Institute of Research and Rehabilitation for Diabetes, Endocrine and Metabolic Disorders, Dhaka, for providing some samples.

\section{References}

1. Bebrone C (2007) Metallo-beta-lactamases (classification, activity, genetic organization, structure, zinc coordination) and their superfamily. BiochemPharmacol 74: 1686-1701.

2. Walsh TR, Toleman MA, Poirel L, Nordmann P (2005) Metallo-beta-lactamases: the quiet before the storm? ClinMicrobiol Rev 18: 306-325.

3. Zhao WH, Hu ZQ (2010) Beta-lactamases identified in clinical isolates of Pseudomonas aeruginosa. Crit Rev Microbiol 36: 245-258.

4. Tsakris A, Pournaras S, Woodford N, Palepou MF, Babini GS, Douboyas J, Livermore DM (2000) Outbreak of infections caused by Pseudomonas aeruginosa producing VIM-1 carbapenemase in Greece. J ClinMicrobiol 38: 12901292.

5. Cornaglia G, Mazzariol A, Lauretti L, Rossolini GM, Fontana R (2000) Hospital outbreak of carbapenem-resistant Pseudomonas aeruginosa producing VIM-1, a novel transferable metallo-beta-lactamase. Clin Infect Dis 31: 11191125 .

6. Ryoo NH, Lee K, Lim JB, Lee YH, Bae IK, Jeong SH (2009) Outbreak by meropenem-resistant Pseudomonas aeruginosa producing IMP-6 metallo-beta-lactamase in a Korean hospital. DiagnMicrobiol Infect Dis 63: 115-117.

7. Chao Z, Xiao-Feng W, Dan-Hong S, Jin-Ping Y, Nan-Shan Z (2008) Outbreak of Pseudomonas aeruginosa producing IMP9-type metallo-beta-lactamase in Guangzhou, China. Int J Antimicrob Agents 32: 363-365.

8. Yong D, Toleman MA, Giske CG, Cho HS, Sundman K, Lee K, Walsh TR (2009) Characterization of a new metallo-betalactamase gene, $b l a_{\mathrm{NDM}-1}$, and a novel erythromycin esterase gene carried on a unique genetic structure in Klebsiellapneumoniaesequence type 14 from India. Antimicrob Agents Chemother 53: 5046-5054.

9. Kumarasamy KK, Toleman MA, Walsh TR, Bagaria J, Butt F, Balakrishnan R, Chaudhary U, Doumith M, Giske CG, 
Irfan S, Krishnan P, Kumar AV, Maharjan S, Mushtaq S, Noorie T, Paterson DL, Pearson A, Perry C, Pike R, Rao B, Ray U, Sarma JB, Sharma M, Sheridan E, Thirunarayan MA, Turton J, Upadhyay S, Warner M, Welfare W, Livermore DM, Woodford N (2010) Emergence of a new antibiotic resistance mechanism in India, Pakistan and the UK: a molecular, biological and epidemiological study. Lancet Infect Dis 10: 597-602.

10. Mulvey MR, Grant JM, Plewes K, Roscoe D, Boyd DA (2011) New Delhi metallo- $\beta$-lactamase in Klebsiellapnemoniae and Escherichia coli, Canada. Emerg Infect Dis 17: 103-106.

11. Poirel L, Lagrutta E, Taylor P, Pham J, Nordmann P (2010) Emergence of metallo- $\beta$-lactamase NDM-1-producing multidrug-resistant Escherichia coli in Australia. Antimicrob Agents Chemother 54: 4914-4916.

12. Poirel L, Revathi G, Bernabeu S, Nordmann P (2011) Detection of NDM-1-producing Klebsiellapneumoniae in Kenya. Antimicrob Agents Chemother 55: 934-936.

13. Clinical and Laboratory Standards Institute (2009) Performance Standards for Antimicrobial Susceptibility Testing: Nineteenth Informational Supplement. CLSI document M100-S19. CLSI: Wayne, PA.

14. Cheesbrough M (1998) Summary of the clinical and laboratory features of microorganisms. In: Cheesbrough M, editor. District Laboratory Practice in Tropical Countries, Part 2. UK: Cambridge University Press. 157-234.

15. Dortet L, Legrand P, Soussy CJ, Cattoir V (2006) Bacterial identification, clinicalsignificance, and antimicrobial susceptibilities of Acinetobacter ursingii and Acinetobacter schindleri, two frequently misidentified opportunistic pathogens. J Clin Microbiol 44: 4471-4478.

16. Andrews JM (2001) Determination of minimum inhibitory concentrations. J Antimicrob Chemother 48: 5-16.

17. Kim SY, Hong SG, Moland ES, Thomson KS (2007) Convenient test using a combination of chelating agents for detection of metallo-beta-lactamases in the clinical laboratory. J Clin Microbiol 45: 2798-2801.

18. Qu T, Zhang J, Jie Wang J, Tao J, Yu Y, Chen Y, Zhou J, Li L (2009) Evaluation of phenotypic tests for detection of metallo-beta-lactamase-producing Pseudomonas aeruginosa strains in China. J Clin Microbiol 47: 1136-1142.

19. Franco MR, Caiaffa-Filho HH, Burattini MN, Rossi F (2010) Metallo-beta-lactamases among imipenem resistant Pseudomonas aeruginosa in a Brazilian university hospital. Clinics 65: 825-829.

20. Zarfel G, Hoenigl M, Leitner E, Salzer HJ, Feierl G, Masoud L, Valentin T, Krause R, Grisold AJ (2011) Emergence of New Delhi metallo- $\beta$-lactamase, Austria. Emerg Infect Dis 17: 129-130.

21. Khan AA, Ponce E, Nawaz MS, Cheng CM, Khan JA, West CS (2009) Identification and characterization of class 1 Integron resistance gene cassettes among Salmonella strains isolated from imported seafood. Appl Environ Microbiol 75: 1192-1196.

22. Mamun KZ, Tabassum S, Shears P, Hart CA (2006) A survey of antimicrobial prescribing and dispensing practices in rural Bangladesh. Mymensingh Med J 15: 81-84.

23. Shibata N, Doi Y, Yamane K, Yagi T, Kurokawa H, Shibayama K, Kato H, Kai K, Arakawa Y (2003) PCR typing of genetic determinants for metallo-beta-lactamases and integrases carried by gram-negative bacteria isolated in Japan, with focus on the class 3 integron. J Clin Microbiol 41: 54075413.

24. Riccio ML, Franceschini N, Boschi L, Caravelli B, Cornaglia G, Fontana R, Amicosante G, Rossolini GM (2000) Characterization of the metallo-beta-lactamase determinant of Acinetobacterbaumannii AC-54/97 reveals the existence of bla(IMP) allelic variants carried by gene cassettes of different phylogeny. Antimicrob Agents Chemother 44: 1229-1235.

25. Lee K, Lee WG, Uh Y, Ha GY, Cho J, Chong Y (2003) VIMand IMP-type metallo-beta-lactamase-producing Pseudomonas spp. and Acinetobacter spp. in Korean hospitals. Emerg Infect Dis 9: 868-871.

26. Koh TH, Wang GCY, Sng LH (2004) IMP-1 and a novel metallo-beta-lactamase, VIM-6, in fluorescent pseudomonads isolated in Singapore. Antimicrob Agents Chemother 48: 2334-2336.

27. Tysall L, Stockdale MW, Chadwick PR, Palepou MF, Towner KJ, Livermore DM, Woodford N (2002) IMP-1 carbapenemase detected in an Acinetobacter clinical isolate from the UK. J Antimicrob Chemother 49: 217-218.

28. Giakkoupi P, Xanthaki A, Kanelopoulou M, Vlahaki A, Miriagou V, Kontou S, Papafraggas E, Malamou-Lada H, Tzouvelekis LS, Legakis NJ, Vatopoulos AC (2003) VIM-1 Metallo-beta-lactamase-producing Klebsiella pneumoniae strains in Greek hospitals. J Clin Microbiol 41: 3893-3896.

29. Fluit AC, Schmitz FT (1999) Class 1 integrons, gene cassettes, mobility, and epidemiology. Eur J Clin Microbiol Infect Dis 18: 761-770.

30. Mendes RE, Toleman MA, Ribeiro J, Sader HS, Jones RN, Walsh TR (2004) Integron carrying a novel metallo-betalactamase gene, blaIMP-16, and a fused form of aminoglycoside-resistant gene aac(6')-30/aac(6')-Ib': report from the SENTRY Antimicrobial Surveillance Program. Antimicrob Agents Chemother 48: 4693-4702.

31. Riccio ML, Pallecchi L, Docquier JD, Cresti S, Catania MR, Pagani L, Lagatolla C, Cornaglia G, Fontana R, Rossolini GM (2005) Clonal relatedness and conserved integron structures in epidemiologically unrelated Pseudomonas aeruginosa strains producing the VIM-1 metallo- $\{$ beta $\}$-lactamase from different Italian hospitals. Antimicrob Agents Chemother 49: 104-110.

32. Mamun KZ, Shears P, Hart CA (1993) The prevalence and genetics of resistance to commonly used antimicrobial agents in faecalEnterobacteriaceae from children in Bangladesh. Epidemiol Infect 110: 447-458.

33. Segal H, Elisha BG (2005) Use of Etest MBL strips for the detection of carbapenemases in Acinetobacterbaumannii. J AntimicrobChemother 56: 598.

34. Ito H, Arakawa $\mathrm{Y}$, Ohsuka S, Wacharotayankun R, Kato N, Ohta M (1995) Plasmid-mediated dissemination of the metallo-beta-lactamase gene blaIMP among clinically isolated strains of Serratiamarcescens. Antimicrob Agents Chemother 39: 824-829.

35. Nishio H, Komatsu M, Shibata N, Shimakawa K, Sueyoshi N, Ura T, Satoh K, Toyokawa M, Nakamura T, Wada Y, Orita T, Kofuku T, Yamasaki K, Sakamoto M, Kinoshita S, Aihara M, Arakawa YJ (2004) Metallo-beta-lactamase-producing gramnegative bacilli: laboratory-based surveillance in cooperation with 13 clinical laboratories in the Kinki region of Japan. Clin Microbiol 2: 5256-5263.

36. Livermore DM (1992) Interplay of impermeability and chromosomal beta-lactamase activity in imipenem-resistant 
Pseudomonas aeruginosa. Antimicrob Agents Chemother 36: 2046-2048.

37. Frere JM (1995) Beta-lactamases and bacterial resistance to antibiotics.Mol Microbiol 16: 385-395.

38. Wolter DJ, Smith-Moland E, Goering RV, Hanson ND, Lister PD (2004) Multidrug resistance associated with mexXY expression in clinical isolates of Pseudomonas aeruginosa from a Texas hospital. Diagn Microbiol Infect Dis 50: 43-50.

39. Xavier DE, Picão RC, Girardello R, Fehlberg LC, Gales AC (2010) Efflux pumps expression and its association with porin down-regulation and beta-lactamase production among Pseudomonas aeruginosa causing bloodstream infections in Brazil. BMC Microbiol 10: 217.

40. Bellais S, Mimoz O, Léotard S, Jacolot A, Petitjean O, Nordmann P (2002) Efficacy of beta-lactams for treating experimentally induced pneumonia due to a carbapenemhydrolyzing metallo-beta-lactamase-producing strain of Pseudomonas aeruginosa. Antimicrob Agents Chemother 46: 2032-2034.
41. Koch-Weser J, Sidel VW, Federman EB, Kanarek P, Finer DC, Eaton AE (1970) Adverse effects of sodium colistimethate. Manifestations and specific reaction rates during 317 courses of therapy. Ann Intern Med 72: 857-868.

42. Yahav D, Farbman L, Leibovici L, Paul M (2012) Colistin: new lessons on an old antibiotic. Clin Microbiol Infect 18: 1829.

\section{Corresponding author \\ Refath Farzana \\ Department of Microbiology \\ Dhaka Medical College \\ Dhaka, Bangladesh \\ Telephone: 9665518; Fax: +8802-8615919 \\ Email: refath_farzana@yahoo.com}

Conflict of interests: No conflict of interests is declared. 